\title{
Survival and Activity of Streptococcus faecalis and Escherichia coli in Tropical Freshwater
}

Inés Muñiz, Luis Jiménez†, Gary A. Toranzos, and Terry C. Hazen ${ }^{*} \dagger$

$$
\begin{aligned}
& \text { Microbial Ecology Laboratory } \\
& \text { Department of Biology } \\
& \text { College of Natural Sciences } \\
& \text { University of Puerto Rico } \\
& \text { Río Piedras, Puerto Rico } 00931
\end{aligned}
$$

Running Title: $\underline{S}$. faecalis in the tropics.

*correspondent author

†Present address: Savannah River Laboratory

Environmental Sciences Division

E. I. du Pont de Nemours \& Company, Inc.

Aiken, South Carolina 29808-0001
RECEIVED

MAY 261998

0.871

Send all correspondence to: Dr. Terry C. Hazen

E. I. du Pont de Nemours \& Company

Savannah River Laboratory

Environmental Sciences Division

Aiken, South Carolina 29808

Submitted to: Appl. Environ. Microbiol.

This paper was prepared in connection with work done under a subcontract to Contract No. DE-AC09-76SR00001 with the U.S.

Department of Energy. By acceptance of this paper, the publisher and/or recipient acknowledges the U.S. Government's right to retain a nonexclusive, royalty-free license in and to any copyright covering this paper, along with the right to reproduce and to authorize others to reproduce all or part of the copyrighted paper.

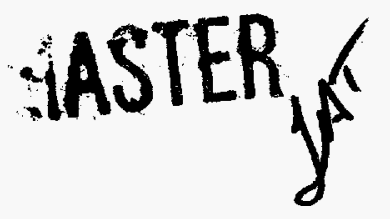




\section{DISCLAIMER}

This report was prepared as an account of work sponsored by an agency of the United States Government. Neither the United States Government nor any agency thereof, nor any of their employees, makes any warranty, express or implied, or assumes any legal liability or responsibility for the accuracy, completeness, or usefulness of any information, apparatus, product, or process disclosed, or represents that its use would not infringe privately owned rights. Reference herein to any specific commercial product, process, or service by trade name, trademark, manufacturer, or otherwise does not necessarily constitute or imply its endorsement, recommendation, or favoring by the United States Government or any agency thereof. The views and opinions of authors expressed herein do not necessarily state or reflect those of the United States Government or any agency thereof.

This report has been reproduced directly from the best available copy.

Available to DOE and DOE contractors from the Office of Scientific and Technical Information, P.O. Box 62, Oak Ridge, TN 37831; prices available from (615) 576-8401.

Available to the public from the National Technical Information Service, U.S. Department of Commerce, 5285 Port Royal Road, Springfield, VA 22161. 


\title{
DISCLAIMER
}

\begin{abstract}
Portions of this document may be illegible in electronic image products. Images are produced from the best available original document.
\end{abstract}




\section{ABSTRACT}

The survival of Streptococcus faecalis and Escherichia coli was studied in situ in a tropical rain forest watershed using membrane diffusion chambers. Densities were determined by acridine orange direct count and Coulter Counter. Population activity was determined by microautoradiography, cell respiration, and by nucleic acid composition. Densities of $\underline{\mathrm{S}}$. faecalis and $\underline{\mathrm{E}}$. coli decreased less than $1 \mathrm{log}$ unit after $105 \mathrm{~h}$ as measured by direct count methods. Activity as measured by respiration, acridine orange activity, and microautoradiography indicated that both bacteria remained moderately active during the entire study. After 12 h, coli was more active than $\underline{S}$. faecalis as measured by nucleic acid composition. E. coli and $\underline{S}$. faecalis survived and remained active this tropical rainbor contamination in tropical waters. 


\section{INTRODUCTION}

In tropical areas of Nigeria (21), Hawaii (10), New Guinea (9), Puerto Rico $(13,15)$, Sierra Leone $(31)$, and the Ivory Coast (17), high densities of Escherichia coli, an indicator of fecal contamination, were found in the complete absence of any known fecal source. Monitoring of (USGS)

Puerto Rican waters by the U.S. Geological Survey, reported that 54 out of 67 water sampling stations on rivers in Puerto Rico exceeded the recommended maximum contaminant levels (MCL) for recreational waters (i.e. $<1,000$ fecal coliforms per $100 \mathrm{ml}$ ) during 1984 (7). Thus only $19 \%$ of all sites sampled met the recommended MCL for recreational waters, and none of these waters could meet raw source water standards ( $<2$ fecal coliforms per $100 \mathrm{ml}$ ). These findings have resulted in condemnation of sewage treatment in Puerto Rico as a source of fecal pollution of natural waters due to improper treatment $(13,15)$. Yet sampling sites upstream from sewage treatment plant outfalls indicated that fecal coliform densities that were just as high as most downstream sites (7).

The reliability of fecal coliform techniques in the tropics has also been questioned. In Puerto Rico, less than $30 \%$ of the fecal coliformpositive isolates from natural waters are confirmed as $\underline{\mathrm{E}}$. coli, whereas more than $90 \%$ of all temperate water isolates are confirmed as $\underline{E}$. coli (25). Pagel et al. (22) compared four fecal coliform assays in various types of freshwaters in Southern Canada. They observed that while these assays were somewhat variable in their abilities to detect fecal coliforms from environmental samples, they were all acceptable in terms of their specificity and selectivity. In similar studies, Santiago- 
Mercado and Hazen (25) used the same methodology to detect fecal coliforms from freshwaters in Puerto Rico and found that the specificity of the media (determined by the ability of the medium to restrict growth of organisms other than the target bacterium) was at least $20 \%$ less than the specificity claimed by the Canadian investigators. Thus all the methods gave significantly higher false positive and false negative errors in tropical waters. Controls using known strains of $\underline{E}$. coli indicated the accuracy of the methods to be the same in both studies. Recent studies have also shown that $\underline{E}$. coli can be isolated from pristine areas of tropical rain forests in Puerto Rico $(4,23)$. Plasmid profiles, antibiotic sensitivities, coliphage susceptibility, and physiological and biochemical characteristics confirm that even E. coli isolated from epiphytes in trees $15 \mathrm{~m}$ above the ground are identical to clinical isolates of E. coli (23). These environmental isolates have identical mole\% $\mathrm{G}+\mathrm{C}$ of the isolates DNA and more than $75 \%$ DNA homology with E. coli B (4). Thus, tropical source waters may have high densities of naturally-occurring E. coli in the absence of pathogens, or fecal sources. Escherichia coli is usually found in higher densities than other enteric pathogens 4 twever, as noted in Botswana (30) and Sierra Leone (31) Salmonella spp., a pathogen, may be found in the complete absence of E. $\underline{\text { coli. }}$.

Water treatment in tropical countries is often deficient $(30,31)$, thus prevalence of disease is exacerbated by the common use of traditional drinking water sources which receive little or no treatment prior to use. In addition, contaminated tropical waters may harbeur a much greater variety of human pathogens, some of which are unique to tropical climes (13). Streptococcus faecalis has often been suggested as 
a possible alternative to E. coli (5). The present study compares the in -

- situ survival and activity of these two bacteria in a tropical river. 


\section{MATERIALS AND METHODS}

Study site. The Mameyes River is located at the northeast corner of the island of Puerto Rico (Fig. 1). The river originates in a cloud rain forest in a pristine portion of the Luquillo Experimental Forest, U. S. Forest Service. For a more complete description of the Mameyes River watershed and site 1 see Carrillo et al. (6).

Water quality. Dissolved oxygen, air temperature, and water temperature were taken with a dissolved oxygen meter (Yellow Springs Instrument, Co., Yellow Springs, Ohio). Three liters of sample water were fixed with either sulfuric acid, zinc acetate, or mercuric chloride, placed on ice and transported to the laboratory for analysis. Nitrates plus nitrites, sulfates, total phosphorus, and phosphates $\left(P_{i}\right)$, were determined in the laboratory as described in Standard Methods for the Examination of Water and Wastewater (2).

Cell densities and activity. Pure cultures of Streptococcus faecalis (CBSC 15-5600A) and Escherichia coli (ATCC 11775) were grown in nutrient broth at $35^{\circ} \mathrm{C}$ for $24 \mathrm{~h}$. Cell densities were adjusted to $10^{8}$ cells $\mathrm{ml}^{-1}$ and the suspension placed into sterile diffusion chambers just prior to immersion at the study site. The chambers and their use are as previously described $(6,14,18,19)$. Four replicate chambers of each bacterial species were suspended $30 \mathrm{~cm}$ below the surface at site 1 . Samples $(2 \mathrm{ml})$ were taken with a sterile syringe at regular intervals for $105 \mathrm{~h}$. Half of each sample was incubated with INT as described by Zimmermann et al. (33). The other half was incubated with $\left[{ }^{3} \mathrm{H}\right]$ thymidine $\left(75 \mu \mathrm{Ci} / \mathrm{m} \mathrm{mol}^{-1}\right)$ for $2.5 \mathrm{~h}$ as described by Tabor and Neihof (28). Samples were fixed in $10 \%$ phosphate-buffered Formalin 
7

( $\mathrm{pH} 7)$, after the appropriate incubation $(28,33)$. Bacterial activity was expressed as respiration (INT reduction (33)), $\left[{ }^{3} \mathrm{H}\right]$ thymidine uptake positive (microautoradiography, (31)), and activity by $\operatorname{AODC}(6,18,19)$. Direct count densities were determined by acridine orange direct counts (19) and Coulter Counter (14).

Data analysis. Programs developed for a Macintosh computer were used for all statistical analyses. Data were subjected to the appropriate transformation before statistical analysis as described by Uar (32). Any statistical probability less $A$ or equal to 0.05 was considered significant. 


\section{RESULTS AND DISCUSSION}

Densities of $\underline{S}$. faecalis were not significantly different than E. coli by either direct count method over time (Fig. 2 and 3). Both bacteria decreased by less than one order of magnitude over the course of the study and the overall trend for the two bacteria is similar. Thus the calculated time for $\underline{S}$ faecalis to decrease by $90 \%$, or one order of magnitude, under if-silu conditions was $>300 \mathrm{~h}$, while E. coli would decrease by $90 \%$ after 276 h. McFeters et al. (20) reported that densities of $\underline{S}$. faecalis decreased by $90 \%$ within $29 \mathrm{~h}$ when exposed to temperate water in situ conditions using diffusion chambers. Bissonnette (Ph. D. thesis, Department of Microbiology, Montana State University, Bozeman, 1974) reported that even in the most sewage contaminated temperate river that $S$. faecalis survival never exceeded $130 \mathrm{~h}$. They also reported that E. coli showed a $90 \%$ reduction in cell density after $30 \mathrm{~h}$ of exposure. Other studies have reported that Streptococcus spp. survive slightly longer than coliforms in temperate waters (10). However other studies by our laboratory have shown that under most conditions $\underline{E}$. coli will survive indefinitely in tropical freshwaters $(6,18,19)$. In addition, no correlation between $S$. faecalis counts and presence of Salmonella spp., a known pathogen, was found in tropical waters in Africa (32), or Sierra Leone (33). In addition, while densities of fecal streptococci are usually lower than densities of fecal coliforms in tropical areas, like the fecal coliforms they seem to be unrelated to known sources of fecal contamination (Wright, 1982; Feachem, 1974; Curtis et al., 1984; Fujioka and Shizumura, 1985; Evison and James, 1973). 
No significant difference in the percentage of respiring cells was observed (Fig. 4). The percentages of respiring cells fluctuated between 3 to $21 \%$ for both bacteria, within the same range reported for naturally occurring bacteria from diverse environmental samples $(30,35)$. This was not surprising considering the oligotrophic nature of the waters in this study, as indicated by the low phosphate concentrations $(0.07$ $\mathrm{mg} / \mathrm{ml}$, Table 1), confirming earlier studies of the same sites (6). However, López-Torres et al. (20) observed a decrease in the percentage of respiring cells for $\underline{E}$. coli at this site from $100 \%$ at time 0 to $10 \%$ after $96 \mathrm{~h}$. The lower percentages observed at the beginning and during the course of the present study, suggest that the bacteria may have been stressed at the beginning of the present study or that the sustaining capacity of the water was even lower than in the present study. The level of respiration observed for both bacteria was high enough to suggest that neither bacteria was under severe stress $(30,35)$.

The proportion of bacterial cells that incorporated $\left[{ }^{3} \mathrm{H}\right]$ thymidine was also not significantly different between bacteria (Fig. 5). The percentage of active cells for both bacteria fluctuated from 3 to $14 \%$, though the average activities for $\underline{E}$. coli were higher at all sampling times, except one (Fig. 5). These levels of $\left[{ }^{3} \mathrm{H}\right]$ thymidine uptake were also typical for naturally-occurring temperate bacterial populations (30). Again suggesting that both bacteria were moderately active.

The percentage of active E. coli cells, as measured by AODC, were significantly higher than $\underline{\mathrm{S}}$. faecalis (Fig. 6; F $=52.9$, df $=1$ and $32, \mathrm{P}<$ 0.0001). But these percentages were lower than those reported for E. coli at the same site $(6,20)$, further suggesting slightly more stressful conditions for the bacteria at the time of this study. AODC activities, as 
determined by the red/red+green cell percent (21), for $\underline{E}$. coli ranged from 55 to more than $90 \%$, while $\underline{S}$. faecalis activity ranged from 25 to $67 \%$. This level of AODC activity has been shown in previous studies to indicate a physiologically active population $(6,20,21)$.

Neither direct count technique showed dramatic changes in density for either bacteria, thus it may be assumed that these bacteria can survive for extended periods (26). However, since these were direct count measurements, the physiological activity of the bacteria must be demonstrated. AODC activity, indicates, like MA and INTreduction, that both bacteria were active in situ in this tropical freshwater stream; however, AODC activity indicated that E. coli . remained at a higher level of activity than $\underline{s}$. faecalis, unlike the assays for MA and INT-reduction. The differences in these activity measurements undoubtedly lie in the differences of each technique. The INT-reduction technique measures respiration via electron transport activity (35). Since both of these bacteria are facultative anaerobes, low levels of respiration did not indicate that these bacteria were not physiologically active. Low levels of $\left[{ }^{3} \mathrm{H}\right]$ thymidine uptake would not indicate that these bacteria were physiologically inactive, only that they were not growing rapidly (30) Since the high levels of AODC activity indicated that protein synthesis was occurring $(20,21)$, and direct counts indicated increases in density after the initial acclimation period, than the bacteria were growing All of the activity measurements confirmed that both bacteria were active. One of the three activity measurements also indicate that E. coli has a higher activity than $\underline{\mathbf{S}}$ faecalis in tropical freshwaters. 
Density of fecal coliforms and presence of Streptococcus spp. in temperate waters has been well demonstrated (14). It has also been suggested that $\underline{E}$. coli is a better indicator for water quality than fecal coliforms $(5,9)$, and that fecal streptococci may be better indicators than fecal coliforms. The present study suggests that these assumptions are incorrect for tropical freshwater. Indeed, E. coli, fecal coliforms, $\underline{\text { S}} . \underline{\text { faecalis, }}$ fecal streptococci do not accurately indicate the presence of these pathogens in tropical waters due to their rate of survival, and possible indigenous nature $(4,17,25)$. Thus, the best indicator for tropical freshwaters is no indicator at all, i.e. enumerate pathogens like Salmonella spp. directly. The technology is available to directly and very specifically monitor or detect pathogens using DNA probes (16) and immunofluorescence techniques (24). Maximum contaminant levels for tropical source waters, based upon certain resistant pathogerns, will be more realistic and attainable regulations that represent a more realistic public health risk. Current tropical source water MCL's based upon fecal coliforms, whose target is E. coli, are unenforceable and may not represent a real public health risk under many circumstances. 


\section{ACKNOWLEDGEMENTS}

We are grateful to Luz Rodriguez, William Arias, Jorge Santo Domingo, Francisco Fuentes, Norma Cruz-Cruz, Yazmín Rojas, Tomás Lugo, and the United States Forest Service for their cooperation, and assistance in this work. We are especially grateful to Carl B. Fliermans who made many helpful suggestions to the manuscript. This work was supported by the Water Resources Research Institute of the University of Puerto Rico at Mayaguez and in part by Sea Grant R/LR-08-87-THA1 and by Public Health Service grants RR-2657 and RR-8102 from the National Institutes of Health. Inés Muñiz was supported by the . undergraduate honor fellowship from the Minority Access to Research Careers (MARC) program of the National Institutes of Health. In addition, portions of the information contained in this article were developed during the course of work under Contract No. DE-AC0976SR00001 with the U. S. Department of Energy. 


\section{LITERATURE CITED}

1. Allen Burton Jr., G., D. Gunnison, and G. R. Lanza. 1987. Survival of pathogenic bacteria in various freshwater sediments. Appl. Environ. Microbiol. 53:633-638.

2. American Public Health Association. 1985. Standard methods for the examination of water and wastewater, 16th ed. American Public Health Association, Washington, D.C.

3. Andre, D. A., H. H. Weiser, and G. W. Maloney. 1967. Survival of bacterial enteric pathogens in farm pond water. J. Amer. Water Works Ass. 59:503-508.

4. Bermúdez, M., and T. C. Hazen. 1988. Phenotypic and genotypic comparison of Escherichia coli from pristine tropical waters. Appl. Environ. Microbiol. 54:979-983.

5. Cabelli, V. J. 1980. What do water quality indicators indicate? p. 305-306. In Colwell, R. R. and J. Foster. (eds), Aquatic microbial ecology. University of Maryland, College Park.

6. Carrillo, M., E. Estrada, and T. C. Hazen. 1985. Survival and enumeration of the fecal indicators Bifidobacterium adolescentis and Escherichia coli in a tropical rain forest watershed. Appl. Environ. Microbiol. 50:468-476.

7. Curtis, R. E., S. Guzman-Ríos, and P. L. Díaz. 1984. Water Resources Data. Puerto Rico and the U.S. Virgin Islands. USGS Survey WaterData Report PR-84-1.

8. Dufour, A. P. 1976. Escherichia coli, the fecal coliform, p. 48-58. In Hoadley, A. W., and B. J. Dutka (ed.), Bacterial indicators/health 
hazards associated with water. American Society for Testing Materials, Philadelphia.

9. Feachem, R. G. 1974. Fecal coliforms and fecal streptococci in streams in the New Guinea highlands. Water Res. 8:367-374.

10. Fujioka, R., and L. K. Shizumura. 1983. Clostridium perfringens, a reliable indicator of stream water quality. J. Water Pollut. Contr. Fed. 57:986-992.

11. Gallagher, T. P., and D. F. Spino. 1968. The significance of coliform bacteria as an indicator of enteric pathogens. Water Res. 2:169175.

12. Geldreich, E. E., L. C. Best, B. A. Kenner, and D. J. Van Donsel. 1968. The bacteriological aspects of stormwater pollution. J. Water Pollut. Contr. Fed. 40:1861-1872.

13. Hazen, T. C. 1988. Fecal coliforms as indicators in tropical waters, a review. Int. J. Tox. Asses. 00:000-000.

14. Hazen, T. C., and G. Esch. 1983. Effect of effluent from a nitrogen fertilizer factory and a pulp mill on the distribution and abundance of Aeromonas hydrophila in Albemarle Sound, North Carolina. Appl. Environ. Microbiol. 45:31-42.

15. Hazen, T. C., F. A. Fuentes, and J. W. Santo Domingo. 1988. In situ survival and activity of pathogens and their indicators. Proc. IV ISME 406-411.

16. Hazen, T. C., and L. Jiménez. 1988. Use of DNA probes to detect bacteria in environmental samples. Microbiol. Sci. 00:000-000.

17. Lavoie, M. C. 1983. Identification of strain isolates as total and fecal coliforms and comparison of both groups as indicators of fecal pollution in tropical climates. Can. J. Microbiol. 29:689-693. 
18. López-Torres, A., T. C. Hazen, and G. A. Toranzos. 1987. Distribution and in situ survival and activity of Klebsiella pneumoniae and Escherichia coli in a tropical rain forest watershed. Curr. Microbiol. $15: 213-218$.

19. López-Torres, A. J., L. Prieto, and T. C. Hazen. 1988. Comparison of the in situ survival and activity of Klebsiella pneumoniae and Escherichia coli in tropical marine environments. Microb. Ecol. $15: 41-57$.

20. McFeters, G. A., G. K. Bissonnette, J. J. Jezeski, C. A. Thomson, and D. G. Stuart. 1974. Comparative survival of indicator bacteria and enteric pathogens in well water. Appl. Environ. Microbiol. 27;823829 .

21. Oluwande, P. A., K. C. Sridhar, A. O. Bammeke, and A. O. Okubadejo. 1983. Pollution level in some Nigerian rivers. Water Res. 17:957963.

22. Pagel, J. E., A. A. Qureshi, D. M. Young, and L. T. Vlassoff. 1982. Comparison of four membrane filter methods for fecal coliform enumeration. Appl. Environ. Microbiol. 43:787-793.

23. Rivera, S., T. C. Hazen, and G. A. Toranzos. 1988. Isolation of fecal coliforms from pristine sites in a tropical rain forest. Appl. Environ. Microbiol. 54:513-517.

24. Roszak, D. B., and R. R. Colwell. 1987. Survival strategies of bacteria in the natural environment. Microbiol. Rev. 51:365-379.

25. Santiago-Mercado, J. and T. C. Hazen. 1987. Comparison of four membrane filtration and MPN methods for fecal coliform enumeration in tropical waters. Appl. Environ. Microbiol. 53:29222928. 
26. Santo Domingo, J. W., F. A. Fuentes, and T. C. Hazen. 1988. Survival and activity of Streptococcus faecalis and Escherichia coli in petroleum-contaminated tropical marine waters. Environ. Pollut. 00:000-000.

27. Seligman, R., and R. Reiter. 1965. Enteropathogens in water with low Escherichia coli titer. J. Am. Water Works Ass. 57:1572-1574.

28. Tabor, P., and J. Neihof. 1984. Direct determination of activities for microorganisms of Chesapeake Bay populations. Appl. Environ. Microbiol. 48:1012-1019.

29. Tabor, P., and J. Neihof. 1982. Improved microautoradiography method to determine individual microorganisms active in substrate uptake in natural waters. Appl. Environ. Microbiol. 44:945-953.

30. Thomson, J. A. 1981. Inadequacy of Escherichia coli as an indicator of water pollution in a tropical climate: A preliminary study in Botswana. South Africa J. Sci. 77:44-45.

31. Wright, R. C. 1982. A comparison of the levels of faecal indicator bacteria in water and human faeces in a rural area of a tropical developing country (Sierra Leone). J. Hyg. 89:69-78.

32. Zar, J. H. 1984. Biostatistical analysis. Prentice-Hall, Inc., Englewood Cliffs, N. J.

33. Zimmermann, R., R. Iturriaga, and J. Becker-Birck. 1978. Simultaneous determination of the total number of aquatic bacteria and the number thereof involved in respiration. Appl. Environ. Microbiol. 36:926-934. 


\section{Figure Legends}

Figure 1. Location of study site in Mameyes River watershed, Puerto Rico.

Figure 2. Changes in total density as measured by AODC for $\underline{\mathbf{S}}$. faecalis and $\underline{E}$. coli (mean \pm one standard error, $n=4$ ).

Figure 3. Changes in total density as measured by Coulter Counter for $\underline{\text { S. faecalis }}$ and $\underline{E}$. coli (mean \pm one standard error, $n=4$ ).

Figure 4. Changes in percent INT-positive cells as measured by INTreduction for $\underline{S}$ faecalis and $\underline{E}$. coli (mean \pm one standard error, $n=4)$.

Figure 5. Changes in percent microautoradiograph positive as measured by $\left[{ }^{3} \mathrm{H}\right]$ thymidine uptake for $\underline{S}$. faecalis and $\underline{\mathrm{E}}$. coli (mean percent of MA \pm one standard error, $n=4$ ).

Figure 6. Changes in percent activity as measured by AODC for S. faecalis and E. coli (mean percent of activity \pm one standard error, $n=4$ ). 
Table 1. Water quality parameters in the Mameyes River watershed.

\begin{tabular}{lllllll}
\hline TIME & WTEMP & ATEMP & $\mathrm{NO}_{2+3}$ & $\mathrm{SO}_{4}$ & TP & $\mathrm{PO}_{4}$
\end{tabular}

\begin{tabular}{lcccccc}
\hline 0 & 18.0 & 19.0 & 0.04 & 0.02 & 0.08 & 0.01 \\
24 & 20.0 & 20.0 & 0.06 & 0.02 & 0.09 & 0.03 \\
48 & 21.0 & 21.0 & 0.03 & 0.03 & 0.05 & 0.01 \\
72 & 19.5 & 19.5 & 0.03 & 0.02 & 0.08 & 0.01 \\
96 & 19.0 & 18.5 & 0.02 & 0.02 & 0.08 & 0.01 \\
105 & $\mathrm{ND}$ & $\mathrm{ND}$ & 0.02 & 0.01 & 0.07 & 0.01 \\
Mean & $19.5 \pm 0.5$ & $19.6 \pm 0.4$ & $0.03 \pm 0.01$ & $0.02 \pm 0.00$ & $0.08 \pm 0.01$ & $0.01 \pm 0.00$ \\
\hline
\end{tabular}

ATEMP $=$ air temperature $\left({ }^{\circ} \mathrm{C}\right), \quad$ WTEMP $=$ water temperature $\left({ }^{\circ} \mathrm{C}\right), \mathrm{SO}_{4}=$ sulfates $(\mathrm{mg} / \mathrm{L}) \mathrm{NO}_{2+3}=$ nitrites plus nitrates $(\mathrm{mg} / \mathrm{L}), \mathrm{TP}=$ total phosphorus $(\mathrm{mg} / \mathrm{L}), \mathrm{PO}_{4}=$ orthophosphates $(\mathrm{mg} / \mathrm{L})$, Mean $=$ mean \pm one standard error, TIME $=$ hours. 


\section{- Mameyes River Watershed}

Alionilc uceon

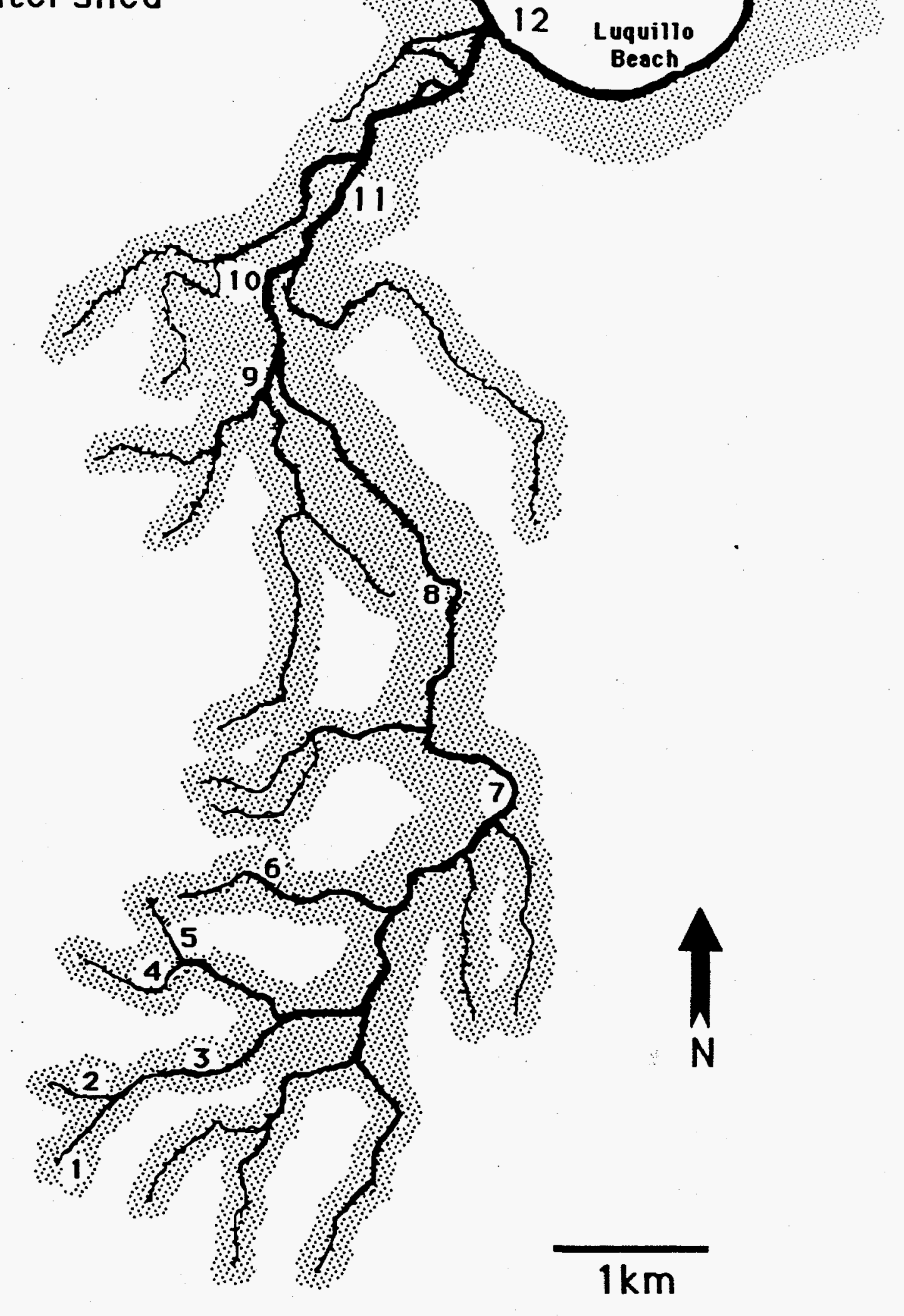




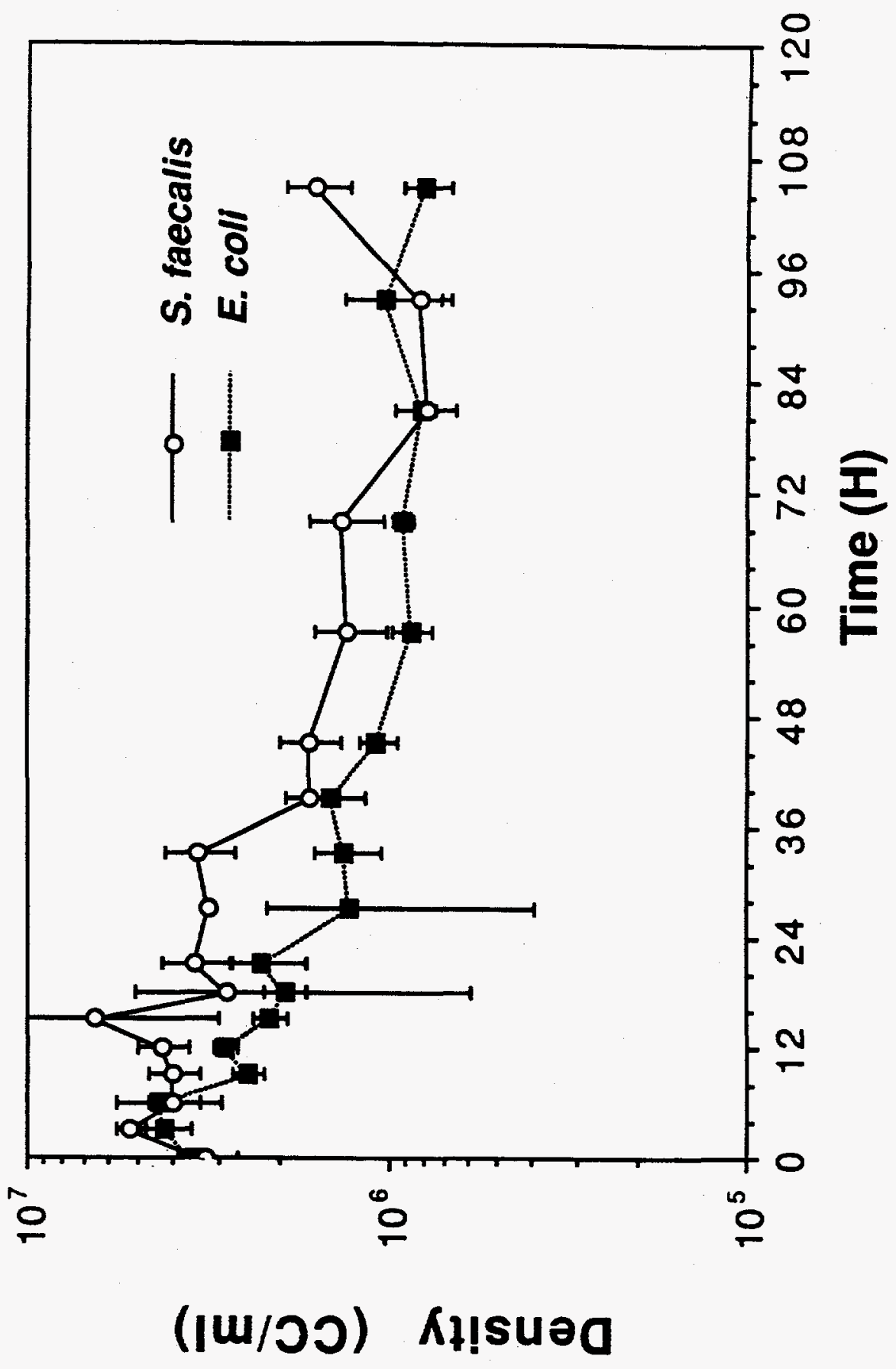




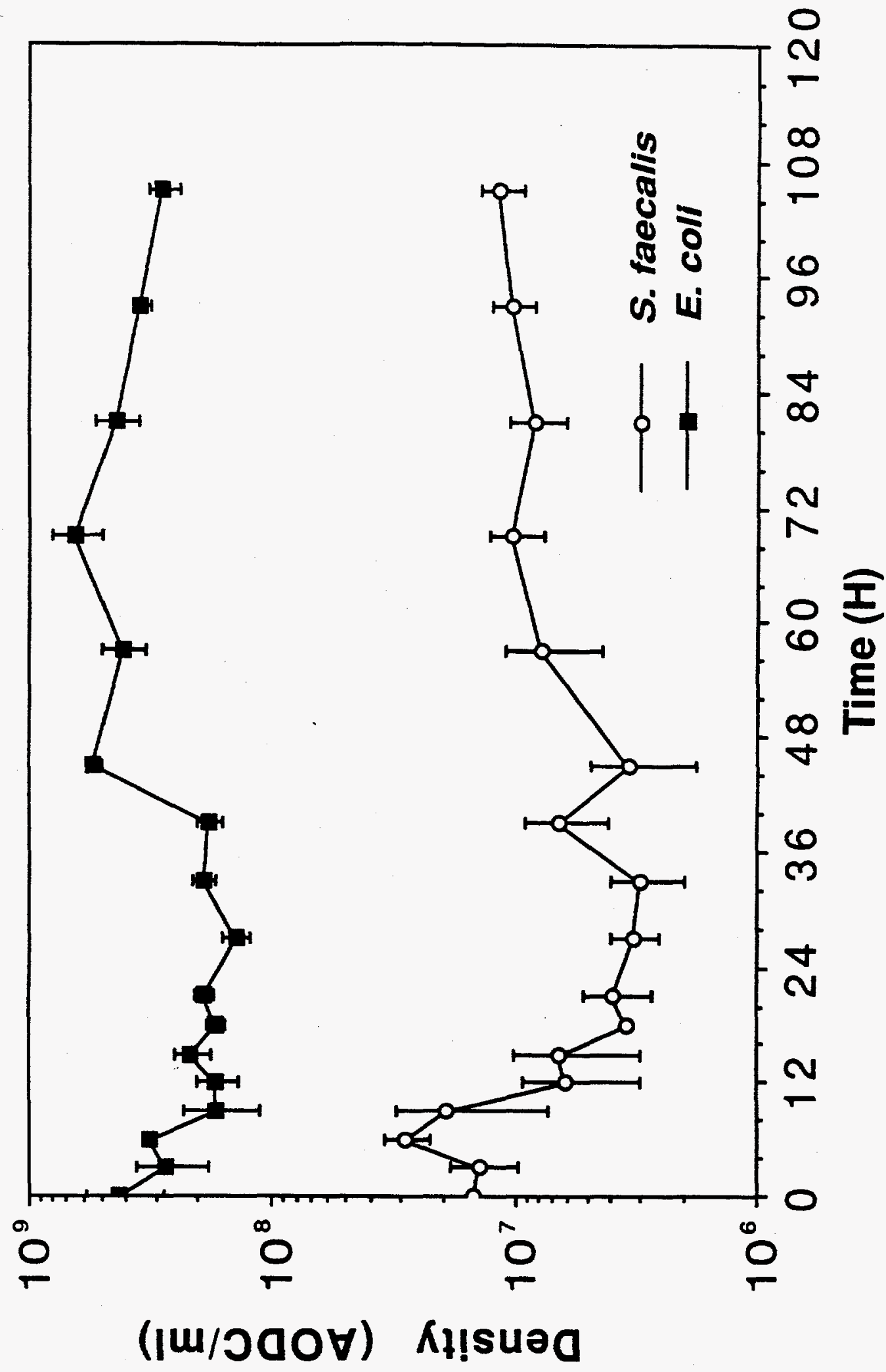




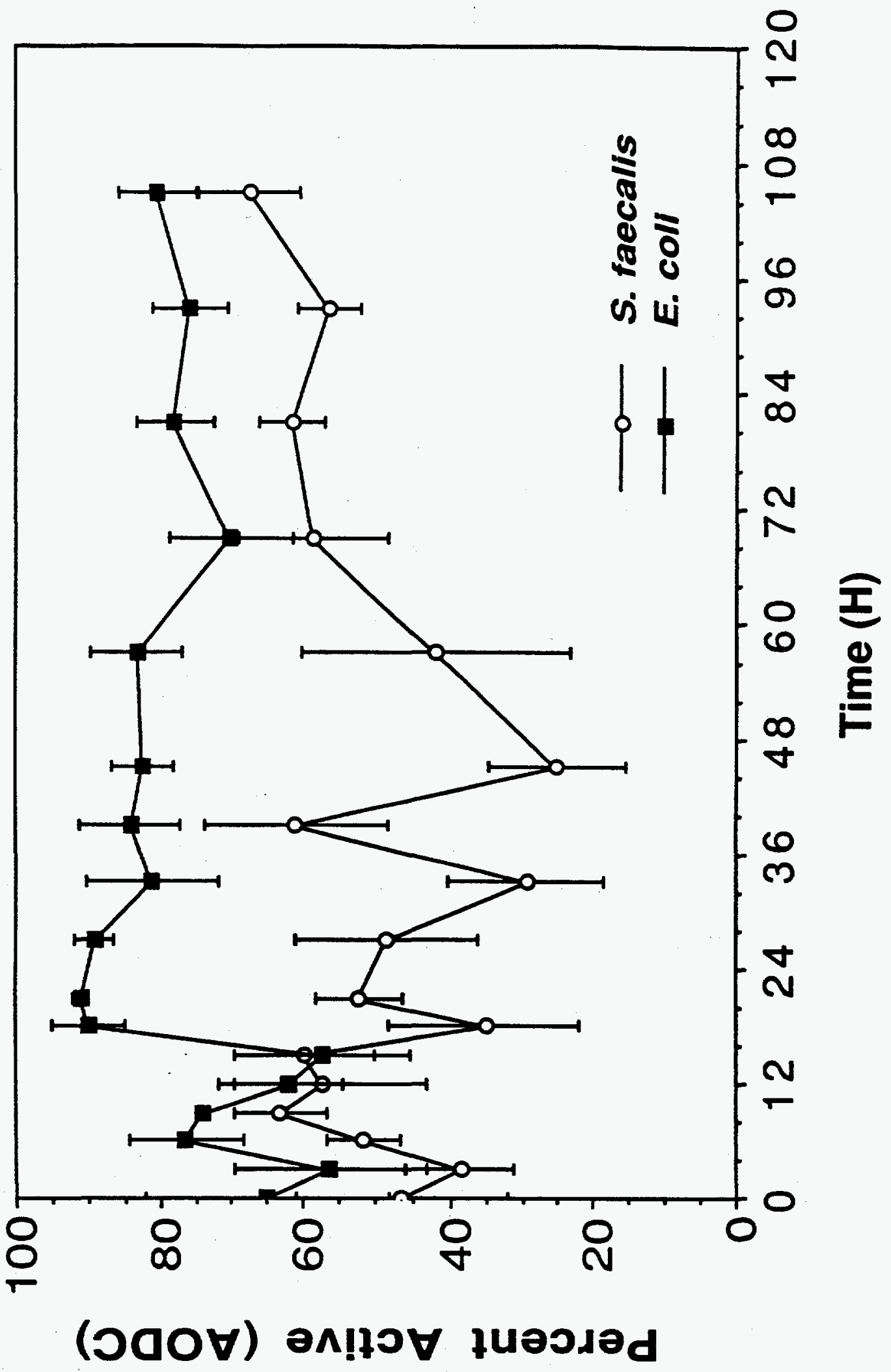




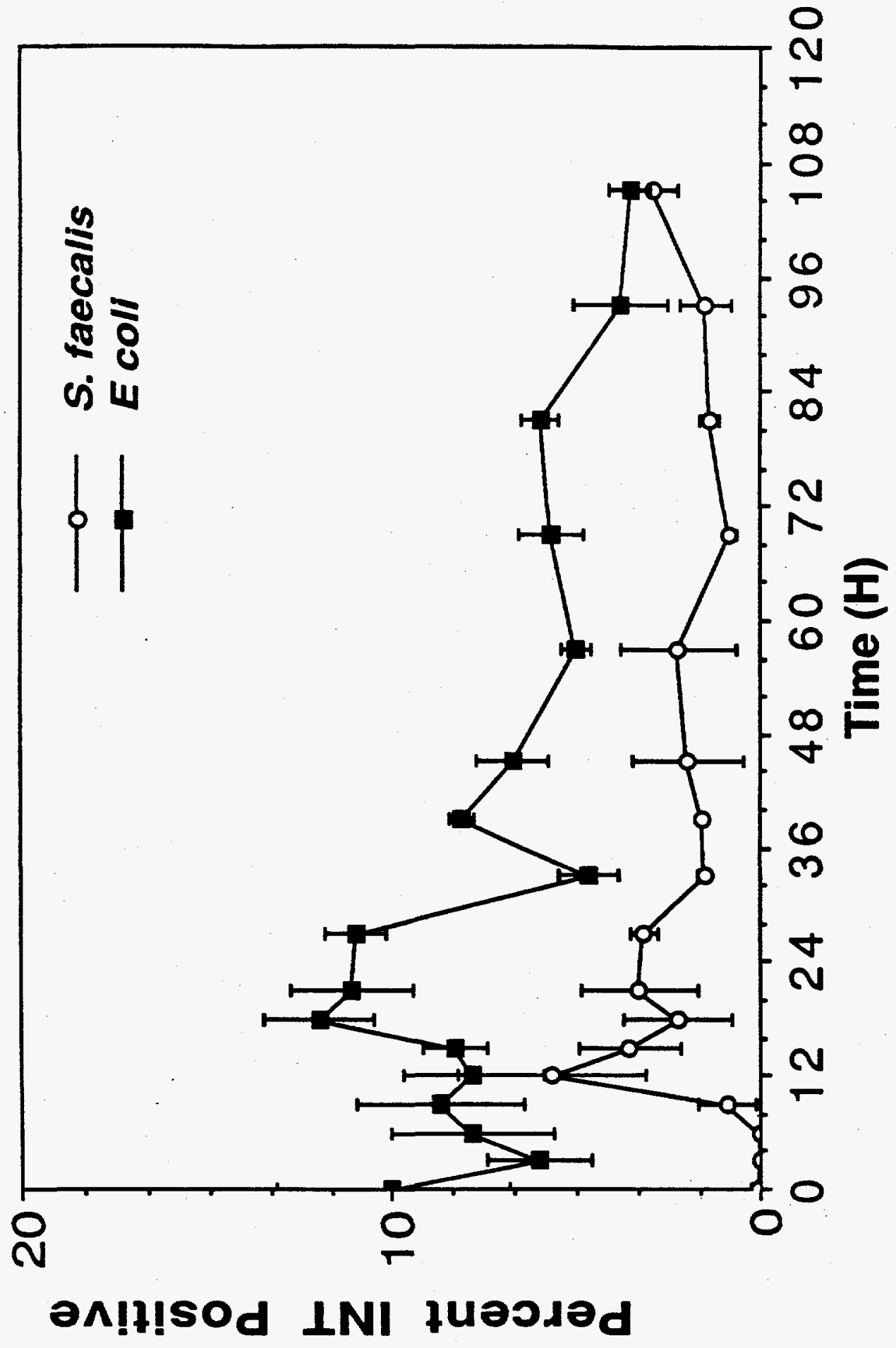




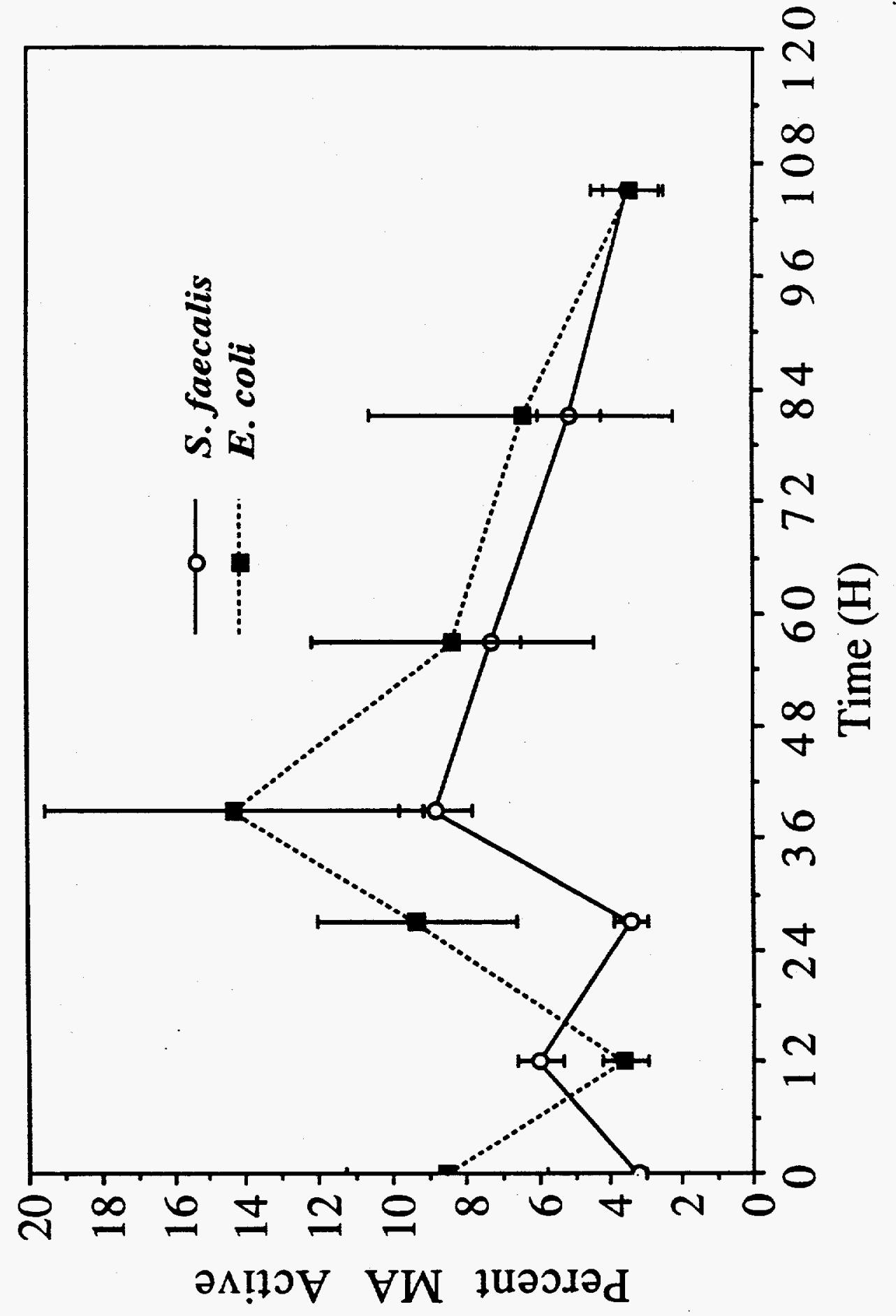

